\title{
Pengenaan Sanksi Denda terhadap Pengusaha Akibat dari Keterlambatan Pembayaran Upah kepada Para Pekerja
}

\author{
I Dewa Ayu Sri Arthayani ${ }^{1}$ \\ ${ }^{1}$ Program Studi Magister (S2) Kenotariatan Fakultas Hukum Universitas Udayana, Bali- \\ Indonesia, E-mail: ayu.arthayani@yahoo.com
}

\begin{abstract}
Info Artikel
Masuk: 28 Januari 2019

Diterima: 20 Pebruari 2019

Terbit: 30 April 2019

Keywords :

workers; wage; amercement

Kata kunci:

Pekerja; Upah; Sanksi Denda

Corresponding Author:

I Dewa Ayu Sri Arthayani, Email:ayu.arthayani@yahoo.com

DOI :

10.24843/AC.2019.v04.i01.p14
\end{abstract}

\begin{abstract}
Based on Article 88 of Law Number 13 of 2003 concerning Manpower, it states that a decent wage for humanity is a right for every worker. In Article 18 of Government Regulation Number 78 of 2015 concerning Wages states that employers are required to pay wages to workers at the agreed time between employers and workers, but in fact there are often delays in payment of wages to workers which of course affect the welfare of workers and his family. then Based on Article 95 number 2 of Law Number 13 of 2003 concerning Labor, states that if the entrepreneur who is due to his intentions or negligence resulting in delays in payment of wages, is subject to a fine. This writing aims to find out how the form of legal protection for workers in the event of late payment of wages and the need for an explanation of the penalties. The research method used in this study is normative legal research. The conclusion in this study is preventive protection (prevention) should companies be able to avoid delay in payment of wages to workers. It is good by the way the company manages the company's finances carefully so that late payment of wages to workers does not occur. Then repressive legal protection (after the dispute) is in accordance with Government Regulation Number 78 of 2015 concerning Wages that companies that delay payment of wages to workers do not only pay wages that are late to be paid, but also pay late fines regulated in this Government Regulations.
\end{abstract}

\begin{tabular}{l}
\hline Abstrak \\
\hline Berdasarkan Pasal 88 Undang-Undang Nomor 13 Tahun 2003 \\
Tentang Ketenagakerjaan menyatakan bahwa upah yang layak \\
bagi kemanusiaan merupakan hak bagi setiap pekerja. Dalam \\
Pasal 18 Peraturan Pemerintah Nomor 78 Tahun 2015 Tentang \\
Pengupahan menyatakan bahwa pengusaha diwajibkan untuk \\
membayarkan upah kepada para pekerja pada ketentuan waktu \\
yang sudah diperjanjikan antara pengusaha dan pekerja, namun \\
dalam kenyataanya kerap terjadi keterlambatan pembayaran \\
upah terhadap para pekerja yang tentu saja mempengaruhi \\
kesejahteraan dari para pekerja dan keluarganya. kemudian \\
Berdasarkan Pasal 95 angka 2 Undang-Undang Nomor 13 \\
Tahun 2003 Tentang Ketenagakerjaan menyebutkan bahwa \\
apabila pengusaha yang dengan kelalaiannya atau \\
kesengajaannya sehingga menyebabkan keterlambatan dalam \\
pembayaran upah, dikenai sanksi denda. Penulisan ini memiliki
\end{tabular}


tujuan untuk mengetahui bagaimanakah bentuk perlindungan

hukum yang dapat diberikan kepada para pekerja dalam hal terjadinya keterlambatan pembayaran upah dan perlu adanya penjelasan mengenai sanksi denda tersebut. Penelitian hukum normatif dipilih untuk digunakan dalam penyusunan penulisan ini Kesimpulan dalam penelitian ini adalah perlindungan secara prefentif (pencegahan) seharusnya perusahaan dapat menghindari terjadinya keterlambatan pembayaran upah kepada para pekerja. Baik dengan cara perusahaan mengatur keuangan perusahaan dengan seksama sehingga keterlambatan pembayaran upah kepada pekerja tidak terjadi. Kemudian perlindungan hukum secara represif (setelah adanya sengketa) yaitu sesuai dengan Peraturan Pemerintah Nomor 78 Tahun 2015 Tentang Pengupahan bahwa perusahaan yang melakukan keterlambatan pembayaran upah kepada para pekerja tidak hanya membayar upah yang terlambat dibayarkan tersebut, melainkan juga membayar denda yang telat diatur dalam Peraturan Pemerintah ini.

\section{Pendahuluan}

Manusia diharuskan untuk bekerja guna melangsungkan dan menunjang kehidupannya, dan dengan bekerjalah harkat dan martabat manusia akan diakui dan dihargai. Kebutuhan manusia sangat beraneka ragam salah satunya terdiri dari tiga kebutuhan pokok yaitu kebutuhan ekonomis, psikis dan biologis. Maka dari itu untuk memenuhi kebutuhan manusia yang sangat beraneka ragam tersebut manusia haruslah bekerja. Baik bekerja yang dapat diusahakan sendiri ataupun dapat bekerja pada orang lain. Apabila bekerja sendiri diartikan sebagai bekerja yang bedasarkan atas sumber usaha modal disertai tanggung jawab dari diri sendiri, kemudian apabila bekerja pada orang lain diartikan sebagai bekerja dengan bergantung pada orang lain dan orang lain tersebut memberikan perintah serta mengutusnya, yang dengan kata lain bahwa bekerja dengan orang lain harus tunduk serta patuh dengan perintah dari orang lain yang memberikan pekerjaan tersebut. ${ }^{1}$ Setiap warga negara Indonesia memiliki hak atas pekerjaan yang layak dan kesamaan untuk turut serta mendapatkan kesempatan bekerja, dan tanpa adanya diskriminasi, hal ini sesuai dengan isi dari Pasal 27 ayat (2) Undang-Undang Dasar Negara Republik Indonesia Tahun 1945 ( UUD 1945). Kesejahteraan dalam kehidupan manusia akan meningkat apabila dirinya bekerja. Manusia bekerja sebagai subyek yaitu pelaku dalam proses produksi bukan hanya sebagai obyek karena manusia memiliki harkat dan martabat. Pada hakekatnya manusia bekerja adalah untuk memperoleh upah. Upah tersebut merupakan bentuk imbalan dari tenaga yang telah pekerja keluarkan, serta upah bagi para pekerja merupakan akibat dari suatu perjanjian kerja yang telah disepakati bersama dengan perusahaan.

Perjanjian kerja telah diatur dalam Pasal 1601 Kitab Undang-Undang Hukum Perdata (KUHPerdata) yang menyebutkan bahwa perjanjian kerja merupakan suatu perjanjian yang mana pihak kesatu yaitu pekerja untuk mengikatkan dirinya untuk dibawah dari perintah pihak lainnya yaitu pengusaha atau atasan untuk suatu waktu dan keadaan

${ }^{1}$ Zainal Asikin. (2012). Dasar-Dasar Hukum Perburuhan, Depok: PT Raja Grafindo Persada, h.1. 
tertentu melakukan suatu pekerjaan dengan maksud dan tujuan untuk menerima upah. Perjanjian merupakan keadaan dari suatu peristiwa bahwa seseorang berjanji dengan seseorang lainnya dan dapat dikatakan dua individu untuk saling berjanji agar melaksanakan sesuatu hal. Pada akhirnya perjanjian menimbulkan adanya suatu perikatan antara dua orang yang menciptakan perjanjian tersebut. ${ }^{2}$

Suatau perjanjian kerja memiliki unsur-unsur yaitu adanya perintah, adanya upah dan serta adanya pekerja. Hak dan kewajiban timbul dengan adanya suatu perjanjian kerja, hak dan kewajiban tersebut dari masing-masing pihak. Dalam setiap perjanjian kerja menciptakan suatu prestasi untuk masing-masing pihak, yang dimaksudkan prestasi digambarkan seperti halnya perusahaan memberikan sesuatu, yang dimaksudkan dari memberikan sesuatu adalah perusahaan memberikan upah kepada para pekerja yang telah bekerja pada perusahaan tersebut. Begitu pula sebaliknya prestasi yang diberikan para pekerja yaitu berbuat sesuatu, mengartikan berbuat sesuatu yaitu bekerja untuk perusahaan yang mana perusahaan tersebut tempat para pekerja tersebut bekerja dan menerima upah.

Perjanjian kerja yang dibuat dan yang telah disepakati oleh masing-masing pihak wajib untuk memenuhi syarat sahnya perjanjian pada umumnya. Mengenai syarat sahnya perjanjian telah diatur dalam Pasal 1320 KUHPerdata. Selanjutnya mengenai perjanjian kerja diatur pula dalam Pasal 52 ayat (1) Undang-Undang Nomor 13 Tahun 2003 tentang Ketenagakerjaan (selanjutnya disingkat UU Ketenagakerjaan) bahwa secara inti perjanjian kerja tercipta atas dasar/berlandaskan kesepakatan dari para pihak kemudian adanya pekerjaan yang telah diperjanjikan dilarang untuk berlawanan atau bertentangan dengan ketertiban umum, kesusilaan dan serta ketentuan peraturan perundang-undangan yang berlaku. Setiap pihak dalam perjanjian kerja tersebut sudah semestinya untuk menjalankan perjanjian kerja dengan sebaik-baiknya sehingga tidak ada salah satu pihak yang merasa dirugikan. Ketika salah satu pihak tidak mengindahkan perjanjian kerja tersebut atau dengan kata lain melakukan kesalahan maka terjadilah wanprestasi. Dapat dikatakan bahwa wanprestasi merupakan suatu keadaan yang mana adanya salah satu pihak tidak melaksanakan ataupun mengindahkan kewajiban karena adanya unsur kesalahan. ${ }^{3}$ Karena semua perjanjian yang telah dibuat dengan sah akan berlaku sebagai undangundang bagi mereka yang telah membuatnya, hal ini sesuai dengan Pasal 1338 ayat (1) KUHPerdata.

Terjadinya wanprestasi dalam suatu perjanjian memang kerap terjadi. Dalam perjanjian kerja wanprestasi yang kerap terjadi adalah keadaan dimana perusahaan terlambat membayar upah kepada para pekerja. Bagi para pekerja upah merupakan hal yang sangat penting karena dengan upah para pekerja dapat melangsungkan kehidupannya bersama keluarganya. Dalam Pasal 88 UU Ketenagakerjaan menyatakan bahwa upah yang layak bagi kemanusiaan merupakan hak bagi setiap pekerja. Dalam

\footnotetext{
2 Rosmanasari, E. (2008). PELAKSANAAN PERLINDUNGAN HUKUM TERHADAP TENAGA KERJA OUTSOURCING PT. INDAH KARYA NUANSA INDONESIA (PT. INKANINDO) DI PT. PERTAMINA (PERSERO) UP-VI BALONGAN (Doctoral dissertation, Program Pasca Sarjana Universitas Diponegoro).

3 Turingsih, R. A. I. (2012). Tanggung Jawab Keperdataan Bidan dalam Pelayanan Kesehatan. Mimbar Hukum-Fakultas Hukum Universitas Gadjah Mada, 24(2), 267-274.
} 
pengertian pasal tersebut bahwa jumlah dari upah yang diterima oleh para pekerja merupakan upah yang dapat memenuhi kebutuhan pekerja beserta keluarganya dengan secara wajar. Dapat dikatakan bahwa penerima upah merupakan pekerja yang bekerja pada pengusaha atau pemberi kerja, dan sedangkan pembayar upah atau yang membayarkan upah adalah pengusaha atau pemberi kerja. ${ }^{4}$

Upah dirasa memegang posisi yang sangat penting dan merupakan suatu cirri khas dalam suatu hubungan kerja, dan setidaknya dapat dikatakan bahwa upah merupakan tujuan yang paling utama dari seorang pekerja untuk melakukan suatu pekerjaan. Kemudian dapat dikatakan pula bahwa upah juga merupakan salah satu wujud dari kompensasi yang mana pekerja menerima suatu imbalan dari pemberi kerja atas suatu pekerjaan maupun jasanya. ${ }^{5}$ Dalam Pasal 1 angka 30 UU Ketenagakerjaan memberikan definisi mengenai upah, bahwa upah merupakan suatu hak yang diterima oleh pekerja, selanjutnya upah tersebut dapat dinyatakan dalam bentuk uang dan diberikan oleh pengusaha atau pemberi kerja sebagai imbalan, upah tersebut kemudian dibayarkan sesuai dengan suatu kesepakatan atau perjanjian kerja dan peraturan perundang-undangan, upah juga termasuk dalam tunjangan untuk pekerja berserta keluarga atas pekerjaan dan/atau jasa yang telah atau akan dilakukan oleh para pekerja. Upah yang telah diberikan oleh pengusaha dipandang sebagai suatu harga yang bersumber dari tenaga yang telah dikeluarkan oleh para pekerja untuk kelangsungan produksi, berkaitan dengan hal tersebut maka upah yang diterima pekerja dapat dibagi menjadi dua macam yang pertama upah nominal, yaitu upah yang secara rutin diperoleh oleh para pekerja dan sejumlah upah tersebut dinyatakan dalam bentuk uang. Kemudian yang kedua yaitu upah riil merupakan suatu kemampuan dari upah nominal yang akan diterima oleh para pekerja apabila upah tersebut ditukarkan dengan barang dan jasa, upah riil diukur berdasarkan jumlah banyaknya barang dan jasa yang dapat diperoleh dari pertukaran tersebut. ${ }^{6}$

Hak dan kewajiban merupakan dua sisi yang tercipta dari setiap hubungan hukum. tidak akan ada hak apabila tidak disertai dengan kewajiban, begitu pun sebaliknya. Dapat dikatakan bahwa hak merupakan suatu kepentingan yang diberikan perlindungan oleh hukum. suatu hak dapat memberikan keleluasaan terhadap sesorang dalam melaksanakannya. Hak dan kewajiban tidak sebagai kumpulan peraturan maupun akidah, hak dan kewajiban adalah perimbangan dari kekuasaan di dalam wujud hak seseorang pada satu pihak yang terwujud pada kewajiban pada pihak lain. sehingga hak dan kewajiban adalah suatu kewenangan yang dapat ditujukan kepada individu oleh hukum. ${ }^{7}$ Bukan hal yang baru apabila terjadi keterlambatan pembayaran upah kepada pekerja, hal ini merupakan sesuatu yang kerap terjadi dalam setiap perusahaan. Dengan adanya keterlambatan pembayaran upah pada pekerja sudah jelas memiliki dampak terhadap para pekerja, baik dampak dalam segi ekonomi dan juga kesejahteraan dari pekerja itu sendiri. Perlu adanya

4 Sayid Mohammad Fifqi Noval. (2017). Hukum Ketenagakerjaan (Hakikat Cita Keadilan Dalam Sistem Ketenagakerjaan). Bandung: PT Refika Aditama, h. 114.

${ }^{5}$ Umar, A. (2012). Pengaruh Upah, Motivasi Kerja, dan Kepuasan Kerja terhadap Kinerja Pekerja pada Industri Manufaktur di Kota Makassar. Jurnal Aplikasi Manajemen, 10(2), 406-418.

6 Sulistiawati, R. (2013). Pengaruh Upah Minimum terhadap Penyerapan Tenaga Kerja dan Kesejahteraan Masyarakat di Provinsi di Indonesia, 200.

7 Hernawan, A. (2012). Keseimbangan Hak dan Kewajiban Pekerja dan Pengusaha dalam Mogok Kerja. Mimbar Hukum-Fakultas Hukum Universitas Gadjah Mada, 24(3), 418-430. 
penelitian yang mengkaji bagaimana bentuk perlindungan hukum bagi para pekerja dan juga sanksi terhadap perusahaan setelah adanya keterlambatan pembayaran upah. Karena masalah pengupahan merupakan masalah yang penting. Perusahaan wajib untuk membayar upah kepada para pekerja sebagaimana mestinya secara teratur dimulai sejak terjadinya hubungan kerja dan sampai dengan hubungan kerja tersebut berakhir. Apabila dilihat dari satu sisi saja para pekerja yang bekerja pada suatu perusahaan akan tentu bertanggungjawab bekerja terhadap perusahaan tempat dimana para pekerja itu bekerja, namun bagaimana dengan tanggungjawab dari pihak perusahaan itu sendiri terhadap para pekerja yang bekerja pada perusahaan tersebut.

\section{Metode Penelitian}

Penelitian hukum normatif dipilih untuk digunakan dalam penyusunan penulisan ini. Penelitian normatif dikatakan sebagai penelitian yang meletakkan hukum sebagai sebuah bangunan sistem norma. Kemudian ada pula yang mengatakan bahwa penelitian normatif merupakan suatu penelitian dimana dilakukan dengan cara meneliti dari bahan kepustakaan. Dalam penyusunan penulisan ini digunakan pendekatan yaitu pendekatan perundang-undangan (statue approach). Dapat dikatakan yang dimaksud dengan statue yaitu berupa legislasi dan regulasi. Selanjutnya dalam teknik pengumpulan bahan hukum dalam penulisan ini dilakukan dengan cara library research dengan sistem kartu, bahwa setelah mendapatkan semua bahan-bahan yang diperlukan kemudian dibuatkan suatu catatan mengenai beberapa hal-hal yang dianggap penting bagi penulisan ini. Setelah itu bahan-bahan hukum yang diperoleh dianalisa dengan teknik deskriptif.

\section{Hasil dan Pembahasan}

\subsection{Bentuk Perlindungan Hukum Terhadap Para Pekerja Dalam Hal Adanya Keterlambatan Pembayaran Upah}

Pekerja merupakan setiap orang atau individu yang melakukan pekerjaan dengan menerima upah dan/atau imbalan dalam bentuk lain, hal ini tercermin dalam Pasal 1 angka 3 UU Ketenagakerjaan yang menjelaskan mengenai apa yang dimaksud dengan pekerja. Definisi tenaga kerja yang telah dijelaskan dalam UU Ketenagakerjaan ini menunjukan bahwa adanya sebuah pemikiran yang sangat luas karena termasuk dalam aspek siapa saja yang mampu atau bisa bekerja, baik berada dalam hubungan kerja (formal) ataupun berada diluar hubungan kerja (informal) dengan memiliki ciriciri yaitu bekerja dengan dibawah perintah orang lain dengan tujuan untuk menerima upah. ${ }^{8}$ Di dalam suatu proses produksi untuk menciptakan atau menghasilkan suatu barang atau jasa maka pekerja merupakan faktor yang digunakan dalam proses produksi. ${ }^{9}$ Berdasarkan kualitas dari para pekerja, pekerja dapat dibagi menjadi 3 macam yaitu pekerja terdidik, pekerja tidak terdidik serta tidak terlatih, dan pekerja yang terlatih. Pekerja terdidik merupakan pekerja yang telah memiliki suatu kemahiran atau keahlian dalam suatu bidang tertentu yang didapatnya dengan cara menempuh jenjang pendidikan formal dan ataupun sekolah, salah satu contohnya adalah dokter. Selanjutnya pekerja tidak terdidik serta tidak terlatih dapat dikatakan

\footnotetext{
8 Sayid Mohammad Fifqi Noval. Op.cit, h.97.

${ }^{9}$ Sulistiawati, R. Op.cit, h.56.
} 
merupakan pekerja kasar yang dalam pekerjaannya hanya mengandalkan tenaga saja seperti contoh kuli bangunan. Kemudian pekerja terlatih merupakan pekerja yang mempunyai suatu keahlian atau kemahiran dalam suatu bidang tertentu, untuk mendapatkan keahlian tersebut para pekerja mengumpulkan pengalaman kerja pada suatu tempat, seperti contoh apoteker.

Pemerintah Indonesia telah menetapkan kebijakan-kebijakan dalam pengupahan. Penetapan kebijakan tersebut bukan tanpa alasan. Tujuan dari pemerintah Indonesia dalam menetapkan kebijakan pengupahan adalah untuk memberikan perlindungan untuk para pekerja, kebijakan pemerintah dalam pengupahan tersebut meliputi upah minimum, upah tidak masuk kerja karena berhalangan, upah kerja lembur , upah tidak masuk kerja karena melakukan kegiatan lain yang ada diluar pekerjaannya, upah karena telah menjalankan hak waktu istirahat kerjanya, bentuk dan cara pembayaran upah, denda dan potongan upah, hal-hal yang dianggap dapat diperhitungkan dengan upah, struktur dan skala pengupahan yang proporsional, serta upah untuk pembayaran pesangon, dan yang terakhir yaitu upah untuk perhitungan pajak penghasilan. Berdasarkan UU Ketenagakerjaan menerangkan mengenai hak dan kewajiban para pekerja dalam melaksanakan pekerjaannya, dan dimana UU Ketenagakerjaan ini berfungsi untuk melindungi serta membatasi status pekerja dari hak dan juga kewajiban para pekerja dari para pemberi kerja yang harus sesuai dengan harkat dan juga martabat kemanusiaan di dalam lingkungan kerja. Karena dapat dikatakan kewajiban pekerja merupakan hak dari pengusaha atau pemberi kerja, sedangkan kewajiban dari pengusaha merupakan hak dari para pekerja.

Dalam penetapan upah terdapat beberapa prinsip-prinsip yaitu upah itu harus adil bahwa besarannya upah yang akan diberikan pengusaha kepada pekerja harus sepadan atau sesuai dengan jenis pekerjaan dan juga resiko pekerjaan, kemudian upah yang diberikan harus layak dan wajar bahwa upah yang diberikan haruslah sesuai dengan pemenuhan kebutuhan hidup para pekerja, upah harus memenuhi kebutuhan yang minimal bahwa setidaknya kebutuhan pokok karyawan dan keluarganya harus terpenuhi, selanjutnya upah harus dapat meningkat dan upah tidak boleh bersifat statis bahwa upah yang diberikan oleh perusahaan kepada pekerja haruslah ditinjau secara bertahap karena adanya perubahan pada peraturan perundang-undangan. Peraturan Pemerintah Nomor 78 Tahun 2015 Tentang Pengupahan (selanjutnya disingkat PP Pengupahan) menjelaskan mengenai tata cara pengupahan. Kerangka bagaimana upah diatur serta ditetapkan merupakan bagian dari sistem pengupahan. Sistem pengupahan yang terdapat di Indonesia pada umumnya dilandaskan pada tiga fungsi upah itu sendiri yaitu untuk terjaminnya kehidupan yang layak untuk pekerja dan beserta keluarganya, mewujudkan suatu imbalan atas usaha dan hasil kerja dari seseorang, dan menyediakan tambahan penghasilan (insentif) untuk agar terciptanya dorongan peningkatan pada produktivitas kerja. Kemudian dalam menetapkan upah terdapat pula berbagai jenis sistem upah yaitu sistem upah jangka waktu, sistem upah potongan, sistem upah pemupakatan, sistem skala upah berubah, upah yang naik turun menurut naik turunnya angka dari indeks biaya penghidupan serta sistem pembagian keuntungan.

Perlindungan hukum dapat dijelaskan sebagai adanya suatu usaha dengan tujuan untuk memberikan hak-hak dari pihak yang dilindungi tersebut untuk dapat disesuaikan dengan kewajiban-kewajiban yang telah dilakukan. Menurut Philipus M 
Hadjon perlindungan hukum untuk masyarakat terdiri dari dua hal, yaitu perlindungan hukum preventif dan perlindungan hukum represif. Yang dimaksud dengan perlindungan hukum preventif adalah suatu bentuk dari perlindungan hukum yang bersifat pencegahan terhadap suatu peristiwa yang tidak pasti. ${ }^{10}$ Sedangkan perlindungan hukum represif yaitu suatu bentuk perlindungan hukum dimana lebih merujuk dalam penyelesaian suatu sengketa. Sesuai dalam Pasal 6 UU Ketenagakerjaan sudah dikatakan bahwa hak dari pekerja adalah untuk mendapatkan perlakuan yang sama tanpa dibeda-bedakan atau diskriminasi dari pengusaha. $\mathrm{H}$. Zainal Asikin menyebutkan bahwa perlindungan kepada pekerja dapat dikategorikan dalam tiga macam yaitu perlindungan ekonomis, perlindungan sosial dan perlindungan teknis.11 Yang dimaksud dengan perlindungan ekonomis yaitu perlindungan kepada para pekerja dalam bentuk penghasilan yang cukup atau layak dan termasuk apabila pekerja tersebut tidak dapat untuk bekerja diluar dari kehendaknya. Selanjuntnya perlindungan sosial adalah perlindungan terhadap para pekerja dalam bentuk seperti diberikannya jaminan kesehatan kepada para pekerja, kemudian perlindungan hak untuk berorganisasi serta kebebasan berserikat para pekerja. Kemudian yang terakhir yaitu perlindungan teknis, perlindungan teknis merupakan perlindungan pekerja dalam bentuk keamanan dan keselamatan kepada pekerja pada saat pekerja melakukan pekerjaannya. Tujuan dari adanya perlindungan hukum terhadap para pekerja yaitu untuk menjamin terjadi atau berlangsungnya suatu hubungan kerja yang secara baik tanpa adanya tekanan-tekanan dari pihak yang dirasa lebih kuat terhadap pihak yang dirasa lebih lemah. Untuk menjaga keselamatan disertai dengan menjalankan pekerjaannya, para pekerja seharusnya wajib mendapatkan perlindungan- perlindungan untuk adanya jaminan dari hak-hak dasar dari para pekerja dan menjamin mendapatkan kesamaan, kesempatan dan serta perlakuan tanpa adanya diskriminasi atas dasar apapun itu untuk terciptanya kesejahteraan bagi para pekerja beserta keluarganya namun tetap harus memperhatikan pesatnya perkembangan dan kemajuan dalam dunia usaha.

Dari penjelasan mengenai perlindungan hukum yang dikemukakan oleh para ahli tersebut, dalam keterlambatan pembayaran upah yang dialami oleh para pekerja maka perlindungan yang dapat diberikan adalah perlindungan secara ekonomis, bahwa memberikan kepada para pekerja penghasilan yang cukup atau layak untuk dapat memenuhi keperluan sehari-hari bagi dirinya dan beserta keluarganya. Kemudian bentuk perlindungan hukum yang dikemukakan oleh Philipus M. Hadjon dalam keterlambatan pembayaran upah kepada para pekerja secara prefentif (pencegahan) seharusnya perusahaan dapat menghindari terjadinya keterlambatan pembayaran upah kepada para pekerja. Baik dengan cara perusahaan mengatur keuangan perusahaan dengan seksama sehingga keterlambatan pembayaran upah kepada pekerja tidak terjadi. Kemudian apabila pekerja mengalami keterlambatan pembayaran upah, perusahaan diwajibkan untuk memberitahu para pekerja terlebih dahulu karena itu merupakan hak bagi para pekerja. Kemudian perlindungan hukum secara represif (setelah adanya sengketa) yaitu sesuai dengan PP Pengupahan bahwa perusahaan yang melakukan keterlambatan pembayaran upah kepada para pekerja tidak hanya

\footnotetext{
${ }^{10}$ Endrawati, N. (2012). Perlindungan Hukum Terhadap Pekerja Anak Di Sektor Informal (Studi Kasus di Kota Kediri). Jurnal Dinamika Hukum, 12(2), 270-283.

11 Zainal Aisikin. Op.cit, h.76.
} 
membayar upah yang terlambat dibayarkan tesebut, melainkan juga membayar denda yang telat diatur dalam Peraturan Pemerintah ini.

\subsection{Sanksi Denda Terhadap Perusahaan Akibat Dari Keterlambatan Pembayaran Upah Kepada Para Pekerja}

Berdasarkan Pasal 18 PP Pengupahan menyatakan bahwa pengusaha pada waktu yang telah diperjanjikan oleh pengusaha dan para pekerja agar pegusaha membayarkan upahnya kepada para pekerja. Berdasarkan Pasal 95 angka 2 UU Ketenagakerjaan menyebutkan bahwa apabila pengusaha yang karena disengaja ataupun kelalaiannya sehingga menyebabkan keterlambatan dalam pembayaran upah kepada pekerja, maka dikenai sanksi berupa denda yang sesuai dengan presentase dari upah pekerja tersebut. Sanksi merupakan hukuman yang negatif terhadap orang yang telah melanggar aturan, kemudian denda merupakan suatu hukuman yang dilaksanakan dengan membayarkan sejumlah uang akibat dari melanggar peraturan disertai juga hukum yang berlaku. Maka dapat disimpulkan bahwa sanksi denda merupakan suatu hukuman yang bersifat negatif dan diterapkan untuk orang-orang yang telah melanggar peraturan dengan membayarkan sejumlah uang. ${ }^{12}$ Mengenai presentase denda diatur dalam Pasal 55 PP Pengupahan. Di dalam Pasal 55 ini dijelaskan mengenai pengusaha yang terlambat membayarkan upah kepada pekerja akan dikenakan denda dengan berbagi ketentuan, yaitu yang pertama dimulai dari hari keempat hingga hari kedelapan terhitung sejak tanggal seharusnya upah para pekerja dibayarkan oleh pengusaha, namun upah terlambat atau tidak dibayar maka pengusaha dikenakan denda sebesar 5\% (lima persen) untuk setiap hari dari tanggal keterlambatan upah yang seharusnya dibayar. Kemudian yang kedua bahwa setelah hari kedelapan tersebut tetapi upah tidak kunjung dibayarkan oleh pengusaha, maka dikenakan denda keterlambatan ditambah jumlahnya menjadi 1\% (satu persen) untuk setip hari keterlambatannya, dengan ketentuan bahwa satu bulan tersebut untuk tidak melewati dari $50 \%$ dari upah yang semestinya dibayarkan pengusaha. Kemudian yang ketiga bahwa apabila sesudah sebulan dan upah masih tidak dibayar oleh pengusaha maka dikenakan denda keterlambatan sebagaimana hal yang sudah disebutkan sebelumnya ditambah dengan bunga sebesar suku bunga yang berlaku pada bank pemerintah.

Walaupun pengusaha telah dikenakan sanksi denda, namun hal itu tidak dapat menghapuskan kewajiban dari pengusaha untuk harus membayarkan upah kepada para pekerja. Apabila pengusaha tidak memenuhi ketentuan untuk membayar denda maka dalam Pasal 59 PP Pengupahan, pengusaha dapat dikenakan sanksi administratif berupa pembatasan kegiatan usaha, teguran tertulis, pemberhentian sementara seluruh atau sebagian alat produksi, serta dapat dikenai pembekuan kegiatan usaha. Kemudian terdapat langkah lainnya yang dapat dilakukan oleh para pekerja yang menginginkan haknya terpenuhi yaitu melalui cara yang telah diatur di dalam Undang-Undang Nomor 2 tahun 2004 Tentang Penyelesaian Perselisihan Perburuhan (selanjutnya disingkat UU Penyelesaian Perselisihan Perburuhan). Dapat dikatakan

\footnotetext{
12 Santi, A. N. (2012). ANALISIS PENGARUH KESADARAN PERPAJAKAN, SIKAP RASIONAL, LINGKUNGAN, SANKSI DENDA DAN SIKAP FISKUS TERHADAP KEPATUHANWAJIB PAJAK (Studi Empiris Pada WPOP di Wilayah KPP Pratama Semarang) (Doctoral dissertation, Fakultas Ekonomika dan Bisnis).
} 
bahwa dasar atau landasan dari adanya perselisihan antara para pekerja dan pengusaha disini adalah adanya perselisihan hak. Pengertian mengenai perselisihan hak adalah suatu keadaan dimana terdapat perbedaan dalam pelaksanaan atau penafsiran pada suatu ketentuan peraturan perundang-undangan, suatu perjanjian kerja, dan peraturan perusahaan serta perjanjian kerja bersama sehingga muncul perselisihan dari tidak terpenuhinya hak-hak, hal ini berdasarkan Pasal 1 ayat (2) UU Penyelesaian Perselisihan Perburuhan.

Terdapat beberapa jalur ataupun cara yang dapat ditempuh berdasarkan UU Penyelesaian Perselisihan Perburuhan dalam upaya penyelesaian perselisihan atas upah, yaitu yang pertama adalah penyelesaian melalui bipartit, dalam penyelesaian perselisihan wajib diusahakan penyelesaiannya lebih dahulu melalui jalur ini secara musyawarah agar tercapainya kata mufakat. Penyelesaian melalui jalur bipartit diharuskan untuk diselesaikan paling lam 30 (tiga puluh) hari sejak tanggal dimulainya perundingan. Namun bila dalam perundingan jalur bipartit ini tercapai kata sepakat dalam penyelesaian permasalahan perselisihan maka selanjutnya dibuatkan suatu perjanjian bersama yang kemudian akan ditandatangani pula oleh para pihak. Kemudian penyelesaian melalui mediasi, dalam melakukan penyelesaian perselisihan dengan jalur mediasi ini dilaksanakan oleh seorang mediator yang berada di setiap kantor instansi yang bertanggungjawab pada bidang ketenagakerjaan pada setiap kabupaten/kota. Setidaknya dalam jangka waktu yang selambat-lambatnya yaitu 7 (tujuh) hari kerja setelah mendapatkan pelimpahan untuk penyelesaian perselisihan maka moderator harus telah melaksanakan suatu penelitian tentang inti dari perkara dan dapat segera mengadakan siding mediasi. Apabila timbul kata sepakat dalam penyelesaian perselisihan melalui cara mediasi ini, maka setelah itu dibuatkan perjanjian bersama yang kemudian akan ditandatangani oleh para pihak dan serta disaksikan oleh moderator serta perjanjian bersama tersebut didaftarkan pada pengadilan hubungan industrial di pengadilan negeri di wilayah hukum dari pihak-pihak yang telah mengadakan perjanjian bersama tersebut dengan tujuan untuk memperoleh akta bukti pendaftaran. Selanjutnya penyelesaian melalui konsoliasi, penyelesaian ini dilaksanakan oleh konsiliator yang telah terdaftar pada kantor instansi yang bertanggungjawab di bidang ketenagakerjaan pada kota/kabupaten. Apabila tercapainya kata sepakat dalam penyelesaian perselisihan melalui konsoliasi maka selanjutnya dibuatkan perjanjian bersama yang telah ditandatangani oleh para pihak dan telah disaksikan oleh konsiliator dan kemudian didaftarkan pada pengadilan hubungan industrial pada pengadilan negeri di wilayah hukum dari para pihak yang telah mengadakan perjanjian bersama dengan tujuan untuk memperoleh akta bukti pendaftaran. Kemudian penyelesaian perselisihan yang terakhir yaitu melalui jalur pengadilan industrial, merupakan sebuah jalur yang dapat dilalui oleh para pekerja dengan mekanisme gugatan yang telah didaftarkan pada Pengadilan Hubungan Industrial yang mewilayahi dari tempat atau kedudukan kerja dari para pekerja dan dengan dasar gugatan perselisihan hak berupa adanya upah dari para pekerja yang terlambat dibayarkan oleh pengusaha.

\section{Kesimpulan}

Perlindungan yang dapat diberikan akibat dari adanya keterlambatan pembayaran upah kepada para pekerja adalah perlindungan secara ekonomis, bahwa memberikan kepada para pekerja penghasilan yang cukup atau layak dengan tujuan agar terpenuhinya kebutuhan sehari-hari bagi dirinya dan keluarganya. Kemudian bentuk 
perlindungan hukum yang dikemukakan oleh Philipus M. Hadjon dalam keterlambatan pembayaran upah kepada para pekerja secara prefentif (pencegahan) seharusnya perusahaan dapat menghindari terjadinya keterlambatan pembayaran upah kepada para pekerja. Baik dengan cara perusahaan mengatur keuangan perusahaan dengan seksama sehingga keterlambatan pembayaran upah kepada pekerja tidak terjadi. Kemudian apabila pekerja mengalami keterlambatan pembayaran upah, perusahaan diwajibkan untuk memberitahu para pekerja terlebih dahulu karena itu merupakan hak bagi para pekerja. Kemudian perlindungan hukum secara represif (setelah adanya sengketa) yaitu sesuai dengan Peraturan Pemerintah Nomor 78 Tahun 2015 Tentang Pengupahan bahwa perusahaan yang melakukan keterlambatan pembayaran upah kepada para pekerja tidak hanya membayar upah yang terlambat dibayarkan tersebut, melainkan juga membayar denda yang telat diatur dalam Peraturan Pemerintah ini.

Di dalam Pasal 55 PP Pengupahan dijelaskan bahwa pengusaha yang terlambat membayarkan upah kepada pekerja dikenai sanksi denda dengan beberapa ketentuan yang pertama dimulai dari hari keempat hingga hari kedelapan terhitung sejak tanggal seharusnya upah dibayarkan oleh pengusaha, namun upah terlambat atau tidak dibayar maka akan dikenakan sanksi denda sebesar 5\% (lima persen) untuk setiap harinya berawal dari keterlambatan upah para pekerja yang seharusnya dibayarkan. Kemudian yang kedua bahwa setelah hari kedelapan tersebut tetapi upah tidak kunjung dibayarkan oleh pengusaha, maka dikenakan denda keterlambatan ditambah jumlahnya menjadi 1\% (satu persen) untuk setip hari keterlambatannya, dengan ketentuan bahwa satu bulan tersebut untuk tidak melewati dari 50\% dari upah yang semestinya dibayarkan pengusaha. Kemudian yang ketiga bahwa apabila sesudah sebulan dan upah masih tidak dibayar oleh pengusaha maka dikenakan denda keterlambatan sebagaimana hal yang sudah disebutkan sebelumnya ditambah dengan bunga sebesar suku bunga yang berlaku pada bank pemerintah. Walaupun pengusaha telah dikenakan denda, hal tersebut tidak menghapus kewajiban dari pengusaha untuk harus membayarkan upah kepada para pekerja.

\section{Daftar Pustaka \\ Buku}

Zainal Asikin. (2012). Dasar-Dasar Hukum Perburuhan, Depok: PT Raja Grafindo Persada.

Sayid Mohammad Fifqi Noval. (2017). Hukum Ketenagakerjaan (Hakikat Cita Keadilan Dalam Sistem Ketenagakerjaan). Bandung: PT Refika Aditama.

\section{Jurnal}

Endrawati, N. (2012). Perlindungan Hukum Terhadap Pekerja Anak Di Sektor Informal (Studi Kasus di Kota Kediri). Jurnal Dinamika Hukum, 12(2).

Handayani, M. T., \& Artini, N. W. P. (2009). Kontribusi pendapatan ibu rumah tangga pembuat makanan olahan terhadap pendapatan keluarga. Piramida.

Hernawan, A. (2012). Keseimbangan Hak dan Kewajiban Pekerja dan Pengusaha dalam Mogok Kerja.Mimbar Hukum-Fakultas Hukum Universitas Gadjah Mada, 24(3).

Rosmanasari, E. (2008). PELAKSANAAN PERLINDUNGAN HUKUM TERHADAP TENAGA KERJA OUTSOURCING PT. INDAH KARYA NUANSA INDONESIA 
(PT. INKANINDO) DI PT. PERTAMINA (PERSERO) UP-VI BALONGAN (Doctoral dissertation, Program Pasca Sarjana Universitas Diponegoro).

Sulistiawati, R. (2013). Pengaruh Upah Minimum terhadap Penyerapan Tenaga Kerja dan Kesejahteraan Masyarakat di Provinsi di Indonesia.

Santi, A. N. (2012). ANALISIS PENGARUH KESADARAN PERPAJAKAN, SIKAP RASIONAL, LINGKUNGAN, SANKSI DENDA DAN SIKAP FISKUS TERHADAP KEPATUHANWAJIB PAJAK (Studi Empiris Pada WPOP di Wilayah KPP Pratama Semarang) (Doctoral dissertation, Fakultas Ekonomika dan Bisnis).

Turingsih, R. A. I. (2012). Tanggung Jawab Keperdataan Bidan dalam Pelayanan Kesehatan. Mimbar Hukum-Fakultas Hukum Universitas Gadjah Mada, 24(2).

Umar, A. (2012). Pengaruh Upah, Motivasi Kerja, dan Kepuasan Kerja terhadap Kinerja Pekerja pada Industri Manufaktur di Kota Makassar. Jurnal Aplikasi Manajemen, 10(2).

\section{Peraturan Perundang-Undangan}

Undang-Undang Dasar Negara Republik Indonesia Tahun 1945.

Kitab Undang-Undang Hukum Perdata.

Undang-Undang Republik Indonesia Nomor 2 Tahun 2004 Tentang Penyelesaian Perselisihan Hubungan Industrial, (Lembaran Negara Republik Indonesia Tahun 2004 Nomor 6).

Undang-Undang Republik Indonesia Nomor 13 Tahun 2003 Tentang Ketenagakerjaan, (Lembaran Negara Republik Indonesia Tahun 2003 Nomor 39).

Peraturan Pemerintah Republik Indonesia Nomor 78 Tahun 2015 Tentang Pengupahan, (Lembaran Negara Republik Indonesia Tahun 2015 Nomor 237, Tambahan Lembaran Negara Republik Indonesia Nomor 5747). 